\title{
Hukum, Masyarakat Dan Kearifan Lokal Sebagai Modal Sosial Di Aceh: Catatan Awal
}

\author{
T. Nazaruddin, Sulaiman, Hasan Basri \\ Universitas Malikussaleh, Aceh, Indonesia
}

\begin{abstract}
In the context of Aceh, its society and social-ecnonomic development, based on a number of literatures, the meaning of local wisdom can be drawn from the values, norms, laws and knowledge formed by religious teachings, beliefs, traditional values and experiences inherited from ancestors ultimately forming a local knowledge system that is used to solve everyday problems by the community. Aceh, as a region, in addition to following national law practices and provisions, also has customary institutions and traditional / cultural values with its own management that involves community leaders who know a great deal about local wisdom in the region. This is where the roles of traditional leaders, religious leaders and socio-cultural figures are considered important in harmonizing local wisdom with spatial regulation and environmentally sustainable development
\end{abstract}

Keywords

Aceh; adat; hokum kearifan aldkal; agama

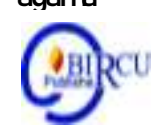

\section{Pendahuluan}

Berbagai kajian dan penelitian selama ini, terkait dengan pengelolaan sumberdaya alam, lingkungan dan tata ruang mencurahkan perhatian serius terhadap kearifan lokal. Berdasarkan sejumlah literatur, dapat ditarik makna kearifan lokal adalah nilai-nilai, norma, hukum-hukum dan pengetahuan yang dibentuk oleh ajaran agama, kepercayaan-kepercayaan, tata nilai tradisional dan pengalaman-pengalaman yang diwariskan oleh leluhur yang akhirnya membentuk sistem pengetahuan lokal yang digunakan untuk memecahkan permasalahanpermasalahan sehari-hari oleh masyarakat.

Cerminan dari kearifan lingkungan masyarakat yang bercorak religio-magis secara konkrit terkristalisasi dalam produk hukum masyarakat lokal, yang dalam ancangan antropologi hukum disebut hukum kebiasaan (customary law), hukum rakyat (folk law), hukum penduduk asli (indigenous law), hukum tidak tertulis (unwritten law), atau hukum tidak resmi (unofficial law), atau dalam konteks Indonesia disebut hukum adat (adat law/adatrecht). Berbagai kajian dan penelitian selama ini, terkait dengan pengelolaan sumberdaya alam, lingkungan dan tata ruang mencurahkan perhatian serius terhadap kearifan lokal. Berdasarkan sejumlah literatur, dapat ditarik makna kearifan lokal adalah nilai-nilai, norma, hukum-hukum dan pengetahuan yang dibentuk oleh ajaran agama, kepercayaankepercayaan, tata nilai tradisional dan pengalaman-pengalaman yang diwariskan oleh leluhur yang akhirnya membentuk sistem pengetahuan lokal yang digunakan untuk memecahkan permasalahan-permasalahan sehari-hari oleh masyarakat. 
Cerminan dari kearifan lingkungan masyarakat yang bercorak religio-magis secara konkrit terkristalisasi dalam produk hukum masyarakat lokal, yang dalam ancangan antropologi hukum disebut hukum kebiasaan (customary law), hukum rakyat (folk law), hukum penduduk asli (indigenous law), hukum tidak tertulis (unwritten law), atau hukum tidak resmi (unofficial law), atau dalam konteks Indonesia disebut hukum adat (adat law/adatrecht). ${ }^{1}$

Sistem kearifan lokal yang tercermin dalam sistem pengetahuan dan teknologi lokal di berbagai daerah secara dominan masih diwarnai nilai-nilai adat sebagaimana tampak dari cara-cara mereka melakukan prinsip-prinsip konservasi, managemen dan eksploitasi sumberdaya alam. ${ }^{2}$ Melalui proses interaksi dan adaptasi dengan lingkungan dan sumberdaya alam yang panjang, masyarakat adat mampu mengembangkan cara untuk mempertahankan hidup dengan menciptakan sistem nilai, pola hidup, sistem kelembagaan dan hukum yang selaras dengan kondisi dan ketersediaan sumberdaya alam di sekitar daerah yang ditinggalinya. ${ }^{3}$

Masyarakat Aceh di masa lalu telah menciptakan berbagai pantangan adat, upacaraupacara tradisional dan juga bermacam tradisi lainnya dalam membina suatu lingkungan yang harmonis. Jika diamati macam-macam unsur kebudayaan yang diciptakan itu dapat menyingkap berbagai pesan yang mempunyai arti perlunya menjaga hubungan yang harmonis dengan lingkungan sekitar. Di antara pesan-pesan tersebut ada yang bersifat sakral magis, sehingga tidak disampaikan secara langsung, melainkan dengan pantangan-pantangan yang penuh dengan makna-makna simbolik. Dengan demikian untuk memaknainya diperlukan pemahaman mendalam terhadap latar belakang sosial-budaya masyarakat Aceh. Di samping itu juga ada ketentuan-ketentuan yang diciptakan namun kemudian diubah karena tidak sesuai lagi dengan perkembangan zaman, misalnya adat-adat atau kebiasaan-kebiasaan yang dapat menimbulkan mudharat bagi masyarakat Aceh.

\section{Kajian Pustaka}

\section{Agama dan Masyarakat Aceh}

Sebagaimana diketahui bahwa orang Aceh sangat fanatik kepada agama Islam yang dianutnya, sehingga hal-hal yang berkaitan dengan adat diperlakukan berdasar kepada kaidah-kaidah hukum agama Islam. Hal ini sesuai dengan ungkapan/filosofi, adat ngon hukom hanjeut cree lagee zat ngon sifeuet, artinya adat dengan syari' at Islam tidak dapat dipisahkan (sudah menyatu), seperti zat dengan sifatnya, atau seperti kuku dengan daging. Dengan demikian tata kehidupan dalam masyarakat Aceh diatur oleh norma-norma adat yang berdasarkan kaidah-kaidah syari'at Islam. ${ }^{4}$

Bagi masyarakat Aceh yang tinggal di gampong (desa), khususnya kawasan hutan, memperlihatkan hubungan yang erat dengan lingkungan hidup. Masyarakat di kawasan hutan mempunyai sikap dan pola pikir yang memegang teguh pada norma dan tradisi yang diwarisi

\footnotetext{
${ }^{1}$ I Nyoman Nurjaya. "Menuju Pengakuan Kearifan Lokal Dalam Pengelolaan Sumber Daya Alam: Perspektif Antropologi Hukum." Dalam Rachmad Safa'at, et.al. Negara, Masyarakat Adat dan Kearifan Lokal. (Malang: In-Trans Publishing, 2008), hlm. 8.

2 Rachmad Safa'at. Rekonstruksi Politik Hukum Pangan dari Ketahanan Pangan ke Kedaulatan Pangan. (Malang: UB Press, 2013), hlm. 3.

${ }^{3}$ Rachmad Safa'at. "Kearifan lingkungan Masyarakat Adat dalam Pengelolaan Sumber Daya Alam Berkelanjutan: Analisis Kasus Masyarakat Adat Baduy dalam Konteks Pelaksanaan Otonomi Daerah." Dalam Rachmad Safa'at, et.al. Negara, Masyarakat Adat dan Kearifan Lokal. (Malang: In-Trans Publishing, 2008), hlm. 61.

${ }^{4}$ Sri Wahyuni, et.al. "Kearifan Lingkungan pada Masyarakat Aceh." Dalam Bunga Rampai Kearifan Lingkungan. (Jakarta: Kementerian Lingkungan Hidup, 2002), hlm. 586.
} 
turun temurun. Kebiasaan saat buka lahan baru, mengikuti norma yang telah ditetapkan oleh "Peutua Adat." Baik berkenaan dengan subjek, objek maupun tata cara pelaksanaannya. Ada larangan-larangan dalam pembukaan lahan di tempat tertentu, yaitu pada sumber mata air. Termasuk dilarang ialah kawasan Guleng Are. Kawasan yang tingkat kemiringannya $15 \%$ ke atas. Maksudnya, suatru kemiringan yang bila are (alat ukur untuk isi beras atau padi yang terbuat dari potongan bambu kapasitas $1.6 \mathrm{~kg}$ ), bila diletakkan akan bergulir. Beralasan untuk memudahkan pengelolaan lahan dan menghindari longsor. ${ }^{5}$

Kearifan lokal dalam tata ruang di berbagai provinsi, seperti pada masyarakat Batak Toba, Sumatera Utara. Dikenal penataan ruang sesuai peruntukannya yaitu;

1. Tano Tarulang: tanah kosong yang belum pernah dikerjakan (statusnya tanah adat/ulayat).

2. Tano na ni ulang: tanah yang sedang di'bera'kan untuk memulihkan kesuburan tanah. Bila masa beranya singkat sekitar 2 tahun dinamai tano dipaombal, bila diberakan untuk waktu yang cukup lama dinamai talun. Bila tanah telantar dalam waktu yang lama dinamai tallik.

3. Harangan: hutan primer (asli) yang belum pernah diolah. Sengaja dibiarkan sebagai kawasan penyangga dari serangan musuh \& tempat sumber bahan untuk peralatan termasuk bahan bangunan.

4. Tombak: hutan sekunder yang pernah diolah, tapi tidak terlihat lagi tanda-tanda pengolahan, seperti pohon buah.

5. Hauma: lahan tempat bercocok tanam \& tanaman padi. Kawasan ini disebut tano maraek (tanah basah).

6. Tano parhutaan: tanah tapak perkampungan.

7. Jalangan atau jampalan: kawasan penggembalaan ternak.

8. Parmualan: kawasan sumber air, seperti mata air (umbul), kawasan ini sengaja dibiarkan menghutan.

9. Sesuai konsep kepercayaan tradisional Batak Toba, kawasan parmualan merupakan kawasan yang dianggap keramat (sakral) yang dinamai sombaon. Kawasan sombaon lainnya ialah puncak gunung, lembah yang dalam, pohon beringin, pekuburan, mata air, pohon2 besar dan hutan primer yang kelam. Kawasan seperti ini tidak boleh dicemari, dirusak atau dieksploitasi. ${ }^{6}$

Kearifan lokal pada pola penataan ruang, didukung dengan sistem subak dan konsep Tri Hita Karana dalam pengelolaan lingkungan hidup juga dapat dilihat pada masyarakat Abiansemal Bali.

Dengan jenis tanah yang ada dan berfungsinya Dam Latu yang memberikan pengairan yang cukup, ditunjang oleh sistem pengaturan pengairan yang dilaksanakan oleh dua subak, yaitu Subak Latu dan Subak Apuan, maka daerah persawahan di desa ini dapat menghasilkan tiga kali panen setahun, dengan variasi pola penanaman padi-palawija-padi atau padi-padi gadu-padi.

Pola perkampungan di Desa Abiansel, pola perkampungan yang memusat, dengan pusat orientasi bale banjar dan balai desa yang terletak pada tempat yang strategis di lingkungan desa. Sebuah balai banjar atau tempat pertemuan warga banjar dikelilingi sejumlah pekarangan penduduk yang menjadi anggota banjar atau kerama banjar. Lokasi pemukiman penduduk yang berorientasi ke tempat-tempat umum menunjukkan pola pengaturan dan pemanfaatan lingkungan permukiman secara fungsional. ${ }^{7}$

\footnotetext{
${ }^{5}$ Sri Wahyuni, et.al. Ibid., hlm. 588.

6 Jonny Purba. "Penataan Ruang Tradisional Sebagai Wujud Kearifan Lingkungan pada Masyarakat Batak Toba.” Dalam Bunga Rampai Kearifan Lingkungan. (Jakarta: Kementerian Lingkungan Hidup, 2002), hlm. 654.

${ }^{7}$ Jonny Purba, Ibid., hlm. 852.
} 
Kearifan lokal dalam tata ruang di Provinsi Aceh, paling nyata melalui keberadaan dan peran Mukim. Mukim telah lahir dan tumbuh selama berabad-abad sejak Zaman Sultan Iskandar Muda. Mukim merupakan kesatuan masyarakat hukum adat yg terdiri atas gabungan beberapa Gampong yang mempunyai batas wilayah tertentu dan harta kekayaan sendiri, berkedudukan langsung dibawah Camat yang dipimpin oleh Imum Mukim. Keberadaannya diakui dan dikukuhkan melalui Qanun Aceh No. 4 Tahun 2003.

Pemerintahan Mukim dilaksanakan oleh tiga unsur yaitu unsur Adat (Imeum Mukim), unsur Agama (Imeum Masjid), dan unsur Dewan (Tuha Lapan). Lembaga Mukim juga dilengkapi dengan lembaga adat yang mengatur pemanfaatan dan pengelolaan sumberdaya alam dan bidang lain di Mukim. Pemanfaatan dan pengelolaan hutan diatur oleh Panglima Uteun, laut oleh Panglima Laot, pelabuhan oleh Syahbanda, kebun oleh Peutua Seuneubok, sawah oleh Keujreun Blang, pasar oleh Haria Peukan, dan sungai oleh Pawang Krueng. Ini membuktikan bahwa penguasaan dan pengelolaan sumberdaya alam khususnya hutan di Aceh telah dipraktekkan dengan kelembagaan dan aturan adat yang jelas. ${ }^{8}$

Keberadaan sistem kearifan lokal pengelolaan sumber daya alam dan lingkungan Mukim, khususnya dalam tata ruang mengalami proses peminggiran, pengabaian dan tidak dilibatkan dalam perencanaan tata ruang, seperti dalam proses penyusunan RTRW Kabupaten Aceh Utara. Dalam Pasal 6 Qanun Kabupaten Aceh Utara No. 14 Tahun 2011 tentang Pemerintahan Mukim disebutkan, "Mukim mempunyai tugas menyelenggarakan pemerintahan kemukiman, melaksanakan pembangunan, melindungi adat dan adat istiadat, membina dan meningkatkan kesejahteraan masyarakat kemukiman dan meningkatkan kualitas pelaksanaan Syari'at Islam." Namun ternyata dalam implementasinya peranan Pemerintahan Mukim masih minim dalam penyelenggaraan pemerintahan. Mukim lebih cenderung difungsikan dalam kegiatan adat istiadat atau penyelesaian sengketa dalam hukum adat. Hal ini sangat mungkin disebabkan oleh masih adanya nuansa pengaruh 'desentralisasi yang sentralistis' dari pelaksanaan Undang-Undang Nomor 5 Tahun 1974 dan UndangUndang Nomor 5 tahun 1979 yang menyeragamkan pola pemerintahan desa di seluruh Indonesia. $^{9}$

Keunggulan-keunggulan kearifan lokal tata ruang masyarakat adat Mukim di Aceh yaitu sinerjinya nilai-nilai Islam dan adat dalam tata ruang yang memberi penguatan terhadap keistimewaan dan kekhususan Aceh; Meunasah (surau) sebagai pencerminan pembangunan nilai-nilai adat dan Masjid sebagai pencerminan pembangunan nilai-nilai Islami, hablumminAllah (hubungan dengan Tuhan) selaras dan seimbang dengan hablumminannas (hubungan dengan sesama manusia dan lingkungan dan tata ruangnya), kuatnya rasa kebersamaan komunal dengan tolong menolong dan silaturahmi sebagai suatu modal sosial (social capital), sebagaimana ungkapan "tulong meunulong sabee keu droe-droe ta peukong nanggroe sabee syedara" (tolong menolong di antara sesama kita perkuat negeri sesama saudara).

Di sisi lain, Undang-Undang Nomor 11 Tahun 2006 Tentang Pemerintahan Aceh (UUPA) dalam konsiderans Menimbang: a. bahwa sistem pemerintahan Negara Kesatuan Republik Indonesia menurut Undang-Undang Dasar Negara Republik Indonesia Tahun 1945 mengakui dan menghormati satuan-satuan pemerintahan daerah yang bersifat khusus atau bersifat istimewa yang diatur dengan Undang-Undang; b. bahwa berdasarkan perjalanan ketatanegaraan Republik Indonesia, Aceh merupakan satuan pemerintahan daerah yang bersifat khusus atau istimewa terkait dengan salah satu karakter khas sejarah perjuangan masyarakat Aceh yang memiliki ketahanan dan daya juang tinggi; c. bahwa ketahanan dan

\footnotetext{
${ }^{8}$ Proposal Pemerintah Aceh-Provinsi Percontohan Redd+ http://forestclimatecenter.org/redd/2011., hlm. 10.

9 Darmawan M. Ali. "Pemerintahan Daerah Berbasis Kearifan Lokal." Disertasi. (Malang: Program Doktor Ilmu Administrasi Universitas Brawijaya, 2013), hlm. 140.
} 
daya juang tinggi tersebut bersumber dari pandangan hidup yang berlandaskan syari'at Islam yang melahirkan budaya Islam yang kuat, sehingga Aceh menjadi daerah modal bagi perjuangan dalam merebut dan mempertahankan kemerdekaan Negara Kesatuan Republik Indonesia;

Dalam Pasal 142 (1) ditentukan, Pemerintah mempunyai kewenangan menetapkan norma, standar, dan prosedur penataan ruang dalam penyusunan Rencana Tata Ruang Wilayah Aceh, dan kabupaten/kota dengan memperhatikan pembangunan berkelanjutan dan kelestarian fungsi lingkungan hidup. (2) Perencanaan, penetapan, dan pemanfaatan tata ruang Aceh didasarkan pada keistimewaan dan kekhususan Aceh dan saling terkait dengan tata ruang nasional dan tata ruang kabupaten/kota.

Secara teoritis: penelitian ini diharapkan berguna untuk pengembangan teoritik di bidang ilmu hukum, terutama hukum tata ruang, hukum adat dan hukum lingkungan serta mengisi kekurangan penelitian di Aceh mengenai kearifan lokal Mukim dalam tata ruang yang berkelanjutan.

Secara praktis: penelitian ini diharapkan berguna untuk dijadikan masukan bagi Pemerintah Kabupaten Aceh Utara, sebagai bahan pertimbangan dalam merevisi Qanun Rencana Tata Ruang Wilayah Kabupaten Aceh Utara yang berbasis kearifan lokal dan berkelanjutan. Bagi masyarakat hukum adat Mukim untuk memperkuat eksistensi dan peran dalam bidang tata ruang. Bagi masyarakat akademik, untuk menerapkan tri dharma penelitian dan pengabdian pada masyarakat dengan meningkatkan partisipasi dalam pembangunan daerah.

Luaran yang ditargetkan adalah: publikasi ilmiah pada jurnal ilmu hukum nasional yang terakreditasi.

\section{Pembahasan}

\section{Politik Hukum}

Kajian teoritik mengenai politik hukum terkait erat dengan pembahasan tentang kebijakan hukum (the policy of law) ${ }^{10}$ yang kemudian menghasilkan berbagai teori tentang kebijakan (policy), antara lain tentang kebijakan publik (public policy). Salah satu studi tentang kebijakan publik dalam sistem hukum negara modern adalah politik hukum (legal politics).

Menurut Moh. Mahfud MD, politik hukum adalah legal policy atau garis (kebijakan) resmi tentang hukum yang akan diberlakukan baik dengan pembuatan hukum baru maupun dengan penggantian hukum lama, dalam rangka mencapai tujuan negara. Dengan demikian, politik hukum merupakan pilihan tentang hukum-hukum yang akan diberlakukan yang kesemuanya dimaksudkan untuk mencapai tujuan negara seperti yang tercantum di dalam pembukaan UUD 1945.

Soerjono Soekanto dan Purnadi Purbacaraka ${ }^{11}$ mengatakan, disiplin politik hukum terbentuk dari gabungan dua disiplin hukum, yaitu disiplin ilmu hukum dan filsafat hukum. Ilmu hukum diarahkan pada cara untuk mencapai tujuan. Adapun filsafat hukum diarahkan untuk melihat tujuan yang diinginkan. Proses interplay antara cara untuk mencapai tujuan dan melihat tujuan yang diinginkan itulah yang kemudian melahirkan politik hukum, dengan catatan bahwa politik dipahami sebagai policy, bukan dalam pengertian cara untuk memperoleh kekuasaan. Dalam hal ini dapat disebut juga kebijakan hukum (legal policy).

\footnotetext{
${ }^{10}$ Mauro Zamboni. The Policy of Law: A Legal theoritical framework. (Oxford and Portland Oregon: Hart Publishing, 2007).

${ }^{11}$ Imam Syaukani dan A. Ahsin Thohari. Dasar-dasar Politik Hukum, cet. Ke-8, (Jakarta: Rajawali Press, 2012), hlm. 40.
} 
Dengan kerangka berfikir seperti ini, maka politik hukum dalam disiplin hukum bergerak pada tataran etik dan teknik kegiatan pembentukan hukum dan penemuan hukum. Politik hukum berbicara pada tataran empiris fungsional dengan menggunakan metode teleologis-konstruktif, artinya bahwa politik hukum dalam pengertian etik dan teknik kegiatan pembentukan hukum dan penemuan hukum, lebih diarahkan untuk melihat sejauh mana hukum yang dibentuk memiliki nilai guna dan gerak dalam proses transformasi masyarakat yang diinginkan, proses yang melibatkan unsur-unsur yang mendukung terjadinya proses tersebut harus diperhatikan, termasuk dalam hal ini adalah pengaruh ideologi atau ajaranajaran politik kendatipun kecil pengaruh tersebut.

Dalam konteks Indonesia maka arah kebijakan hukum yang hendak dibuat atau dibangun selain bertujuan untuk menciptakan sistem hukum nasional, ${ }^{12}$ yang lebih penting adalah untuk mewujudkan kesejahteraan masyarakat. Inilah yang oleh Bagir Manan dikatakan sebagai salah satu bagian dari politik hukum yang bersifat tetap. ${ }^{13}$ Hal ini selaras dengan pendapat Abdul Hakim G. Nusantara bahwa hukum yang hendak dibangun seyogianya harus senantiasa mengacu pada cita-cita masyarakat bangsa, yaitu tegaknya negara hukum yang demokratis dan berkeadilan sosial. Atas dasar pandangan yang demikian dikatakan bahwa politik hukum Indonesia sesungguhnya harus berorientasi pada cita-cita negara hukum yang didasarkan atas prinsip-prinsip demokrasi dan berkeadilan sosial dalam suatu masyarakat Bangsa Indonesia yang bersatu sebagaimana tertuang dalam Pembukaan UUD 1945. ${ }^{14}$ Elaborasi pendapat di atas semakin memperjelas betapa urgennya politik hukum dalam pembentukan, pelaksanaan dan pengembangan hukum. Untuk itu politik hukum harus dirumuskan secara jelas. ${ }^{15}$

Politik hukum dalam praktik penyusunan rencana tata ruang yang dilaksanakan di Indonesia, baik pada tataran Provinsi maupun Kabupaten/Kota, selama beberapa dekade bercorak sentralistik (pemusatan pada pihak eksekutif dengan menisbikan peran legislatif dan masyarakat), elitis, rasionalis (menjunjung tinggi logika dan asumsi deduktif dan prosedur ilmiah), deterministik (upaya menyeragamkan model dan program dengan berlindung di balik efisiensi), dualisme (pemisahan ranah teori dan praktek) dan prosedural terjadilah kolaborasi antara birokrasi pemerintah dengan korporasi konsultan perencana (planner) yang hanya berfungsi sebagai analis belaka dengan rasionya mengolah data belaka, kemudian membuat asumsi-asumsi (dugaan) yang acapkali tidak melihat fenomena empirik. ${ }^{16}$

\section{Kebijakan Publik}

Pemahaman umum terhadap kebijakan publik (public policy), paling tidak berkisar pada tiga hal penting yaitu: perumusan kebijakan publik, implementasi kebijakan publik, dan evaluasi kebijakan. Istilah 'kebijakan' yang dimaksud sepadan dengan kata 'policy' yang dibedakan dari kata 'kebijaksanaan' dan kata 'sosial.' Kebijakan adalah prinsip atau cara bertindak yang dipilih untuk mengarahkan pengambilan keputusan. Pilihan keputusan kebijakan tersebut sebagai prinsip-prinsip yang mengatur tindakan yang diarahkan kepada tujuan-tujuan tertentu. Artinya bahwa kebijakan merupakan suatu ketetapan yang memuat prinsip-prinsip untuk mengarahkan cara-cara bertindak yang dibuat secara terencana dan

${ }^{12}$ C.F.G. Sunaryati Hartono. Politik Hukum Menuju Satu Sistem Hukum Nasional. (Bandung: Alumni, 1991), hlm. 1-2.

${ }^{13}$ Bagir Manan. Menyongsong Fajar Otonomi Daerah. (Yogyakarta: FH UII, 2001), hlm. 180.

${ }^{14}$ Abdul Hakim G. Nusantara. Politik Hukum Indonesia. (Jakarta: YLBHI, 1988), hlm. 20.

15 Adi Sulistiyono. Negara Hukum: Kekuasaan, Konsep, dan paradigma Moral. (Surakarta: LPP dan UNS Press, 2008), hlm. 52. Sebagaimana dikutip oleh Muhammad Akib. Politik Hukum Lingkungan. (Jakarta: PT. RajaGrafindo Persada, 2013), hlm. 6.

${ }^{16}$ Imam Koeswahyono. Hukum Penatagunaan Tanah dan Penataan Ruang di Indonesia, (Problematika antara Teks dan Konteks). (Malang: UB Press, 2012), hlm. 104. 
konsisten dalam mencapai tujuan tertentu. ${ }^{17}$

Sedangkan kata "public policy" yang seringkali diterjemahkan bebas menjadi 'kebijakan publik,' dalam khasanah ilmu administrasi publik dimaknai secara beragam yaitu tergantung sudut mana akan digunakan. Menurut M. Solly Lubis, policy atau kebijakan ini "tertuang dalam dokumen resmi, bahkan dalam beberapa bentuk peraturan hukum, misalnya di dalam UU, PP, Keppres, Peraturan Menteri (Permen), Perda dan lain-lain. ${ }^{18}$

Definisi tunggal mungkin tidak pernah ada, tapi kita bisa melihat atribut kunci dari kebijakan publik:

a. Kebijakan yang dibuat sebagai tanggapan terhadap beberapa jenis masalah yang memerlukan perhatian.

b. Kebijakan yang dibuat atas nama "publik."

c. Kebijakan yang berorientasi pada tujuan atau keadaan yang diinginkan, seperti solusi dari masalah.

d. Kebijakan yang pada akhirnya dilakukan oleh pemerintah, bahkan jika ide datang dari luar pemerintah atau melalui interaksi aktor pemerintah dan non pemerintah.

e. Kebijakan ditafsirkan dan dilaksanakan oleh aktor-aktor publik dan swasta yang memiliki interpretasi yang berbeda dari masalah, solusi, dan motivasi mereka sendiri.

f. Kebijakan adalah apa yang pemerintah pilih untuk melakukan atau tidak melakukan. ${ }^{19}$

\section{Perencanaan Wilayah dan Tata Ruang}

Pendekatan perencanaan telah mengalami perkembangan. Hal ini terjadi sehubungan dengan pengalaman mengenai tingkat keefektifan rencana tersebut. Berdasarkan tipologinya maka pendekatan perencanaan wilayah dan kota umumnya dapat dibedakan atas tiga macam yaitu:

a. Pendekatan perencanaan rasional menyeluruh

'Perencanaan rasional menyeluruh' atau Rational Comprehensive Approach secara konsepsual dan analitis mencakup pertimbangan perencanaan yang luas. Di dalam pertimbangan tersebut tercakup berbagai unsur atau subsistem yang membentuk suatu organisme atau sistem secara menyeluruh. Pertimbangan ini termasuk pula hal-hal yang berkaitan dengan seluruh rangkaian tindakan pelaksanaan serta berbagai pengaruhnya terhadap usaha pengembangan. 'Produk perencanaan rasional menyeluruh' mencakup suatu totalitas dari seluruh aspek tujuan pembangunan. Jadi permasalahan yang ditinjau tidak dilihat secara terpilah-pilah melainkan dalam suatu cakupan kesatuan. Jadi ciri-ciri utama dari suatu pendekatan perencanaan rasional menyeluruh ini adalah sebagai berikut (Banfield, Meyerson):

1. Dilandasi oleh suatu kebijaksanaan umum yang merumuskan tujuan yang ingin dicapai sebagai suatu kesatuan yang utuh.

2. Didasari oleh seperangkat spesifikasi tujuan yang lengkap, menyeluruh dan terpadu.

3. Peramalan yang tepat serta ditunjang oleh sistem informasi (data) yang lengkap, andal dan rinci.

4. Peramalan yang diarahkan pada tujuan-tujuan jangka panjang.

\footnotetext{
17 Mustafa Lutfi \& Luthfi J. Kurniawan. Perihal Negara, Hukum dan Kebijakan Publik. Perspektif Politik Kesejahteraan, Kearifan Lokal, yang pro Civil Society dan Gender. (Malang: Setara Press, 2012), hlm. 13.

${ }^{18}$ M. Solly Lubis. Kebijakan Publik. (Bandung: Mandar Maju, 2007), hlm. 5.

19 Thomas A. Birkland. An Introduction to the Policy Process, Theories, Concepts, and Models of Public Policy Making. Third Edition. (New York: M.E. Sharpe, Inc., 2011), hlm. 8.
} 
Produk perencanaan rasional menyeluruh ini dikenal antara lain sebagai 'Rencana Induk' - Masterplain, 'Rencana Umum' - General Plan, atau 'Rencana Pembangunan' Development Plan (Melville C. Branch). ${ }^{20}$

b. Pendekatan perencanaan terpilah

Dengan adanya anggapan kekurangefektifan pendekatan penyeluruh maka telah dikemukakan suatu bentuk pendekatan perencanaan yang dikenal sebagai 'Pendekatan Perencanaan Terpilah' - Disjointed Incremental planning Approach (Charles E. Linblom dkk).

Pada hakekatnya pendekatan ini mengutamakan unsur atau subsistem tertentu sebagai yang perlu diprioritaskan tanpa perlu melihatnya dalam wawasan yang lebih luas. Pendekatan ini dianggap memungkinkan bagi para pembuat keputusan untuk menerapkan strategi pengambilan keputusan dengan kapasitas kognitif yang terbatas dan lebih rasional. Suatu perencanaan pendekatan ini dianggap terpilah tidak perlu ditunjang oleh sistem informasi yang lengkap, menyeluruh serta akurat mengenai keadaan keseluruhan, cukup data yang terinci tentang unsur atau subsistem tertentu yang diprioritaskan tersebut. Ini dianggap sebagai suatu penghematan dana waktu untuk penelaahan, analisis, dan proses teknis penyusunan rencana.

c. Perencanaan terpilah berdasarkan pertimbangan menyeluruh

'Pendekatan perencanaan terpilah berdasar pertimbangan menyeluruh' ini melihat potensi yang terkandung di kedua pendekatan perencanaan terdahulu. Jadi, pada hakekatnya pendekatan ini mengkombinasikan pendekatan rasional menyeluruh dan pendekatan terpilah masing-masing dalam kadar lingkup tertentu yaitu menyederhanakan tinjauan menyeluruh dalam lingkup 'wawasan sekilas' (scanning) dan memperdalam tinjauan atas unsur atau subsistem yang strategis atau urgen dalam kedudukan sistem terhadap permasalahan menyeluruh.

Oleh karena itu, maka pendekatan perencanaan ini disebut sebagai 'Pendekatan Perencanaan Terpilah Berdasar Pertimbangan Menyeluruh' - 'Mixed Scanning Planning Approach' atau disebut juga sebagai 'Third Planning Approach' - 'Pendekatan Ketiga' (Amitai Etzioni). ${ }^{21}$

Aspek-aspek yang mempengaruhi dalam penataan ruang meliputi, aspek teknis, ekonomi, sosial, budaya, hukum, kelembagaan dan lingkungan. ${ }^{22}$

\section{Modal Sosial}

Modal sosial dapat diartikan sebagai sumber (resource) yang timbul dari adanya interaksi antara orang-orang dalam suatu komunitas. Namun demikian, pengukuran modal sosial jarang melibatkan pengukuran terhadap interaksi itu sendiri. Melainkan, hasil dari interaksi tersebut, seperti terciptanya atau terpeliharanya kepercayaan antar warga masyarakat. Sebuah interaksi dapat terjadi dalam skala individual maupun institusional. Secara individual, interaksi terjadi manakala relasi intim antara individu terbentuk satu sama lain yang kemudian melahirkan ikatan emosional. Secara institusional, interaksi dapat lahir pada saat visi dan tujuan organisasi lainnya. ${ }^{23}$

\footnotetext{
${ }^{20}$ Djoko Sujarto. Pilihan Strategis Suatu teknik Pengambilan Keputusan dalam Perencanaan Wilayah dan Kota. (Bandung: Penerbit ITB, 2001), hlm. 2.

${ }^{21} \mathrm{Ibid}$, hlm. 4.

${ }^{22}$ Robert J. Kodoatie, et.al. Tata Ruang Air. Pengelolaan Bencana, Pengelolaan Infrastruktur, Penataan Ruang Wilayah, Pengelolaan Lingkungan Hidup. (Yogyakarta: Penerbit Andi, 2010), hlm. 406.

${ }^{23}$ Edi Suharto. Modal Sosial dan Kebijakan Publik. Http://www.policy.hu/suharto, diunduh tanggal 6 Juli 2014., hlm. 2.
} 
Berbeda dengan modal manusia, modal sosial juga menunjuk pada kemampuan orang untuk berasosiasi dengan orang lain (Coleman). Bersandar pada norma-norma dan nilai-nilai bersama, asosiasi antar manusia tersebut menghasilkan kepercayaan yang pada gilirannya memiliki nilai ekonomi yang besar dan terukur (Fukuyama). Merujuk pada Ridell, ada tiga parameter modal sosial, yaitu kepercayaan (trust), norma-norma (norms), dan jaringanjaringan (networks). ${ }^{24}$

\section{Pluralisme Hukum}

Pluralisme hukum (legal pluralism) kerapkali diartikan sebagai keragaman hukum. Menurut John Griffiths, pluralisme hukum adalah hadirnya lebih dari satu aturan hukum dalam sebuah lingkungan sosial ${ }^{25}$, dalam hal ini bukan hanya hukum negara dan hukum adat tetapi juga termasuk hukum kebiasaan dan hukum agama ${ }^{26}$.

Terkait dengan pluralisme hukum, terdapat beberapa tipe. Tipe pertama, disebut pluralisme relatif, pluralisme lemah atau pluralisme hukum negara menunjuk pada konstruksi hukum yang di dalamnya aturan hukum yang dominan memberi ruang, implisit atau eksplisit, bagi jenis hukum lain, misalnya hukum adat atau hukum agama. Hukum negara mengesahkan dan mengakui adanya hukum lain dan memasukkannya dalam sistem hukum negara. Tipe kedua, disebut pluralisme kuat atau deskriptif (Griffiths) atau pluralisme dalam (Woodman), pluralisme hukum menunjuk situasi yang di dalamnya dua atau lebih sistem hukum hidup berdampingan, dengan masing-masing dasar legitimasi dan keabsahannya. ${ }^{27}$

Dalam perkembangan selanjutnya, konsep pluralisme hukum tidak lagi mengedepankan dikotomi antara sistem hukum negara (state law) di satu sisi dengan sistem hukum rakyat (folk law) dan hukum agama (religious law) di sisi yang lain. Pada tahap perkembangan ini, konsep pluralisme hukum lebih menekankan pada interaksi dan ko-eksistensi berbagai sistem hukum yang mempengaruhi bekerjanya norma, proses, dan institusi hukum dalam masyarakat. ${ }^{28}$

\section{Otonomi Khusus Aceh}

Aceh merupakan salah satu daerah provinsi di Indonesia yang mempunyai status "otonomi khusus" pada tahun 2001 melalui UU No. 18 Tahun 2001 tentang Otonomi Khusus bagi Provinsi Nanggroe Aceh Darussalam. Bersama Papua, Aceh merupakan kawasan yang paling bergejolak dengan potensi kepada disintegrasi dari Republik Indonesia ${ }^{29}$ Sejak awal kemerdekaan, Aceh menghendaki menjadi kawasan dengan perlakuan khusus. Kehendak ini diperjuangkan dengan sejumlah alasan penting. Dari sejumlah alasan yang berkembang, alasan yang paling kuat adalah alasan kesejarahan.

\footnotetext{
${ }^{24}$ Ibid., hlm. 4.

${ }^{25}$ John Griffiths, "What is Legal Pluralism", Journal of Legal Pluralism and Unoficial Law. Number 24/1986, hlm. 1.

${ }^{26}$ Rikardo Simarmata, "Mencari Karakter Aksional dalam Pluralisme Hukum" dalam Tim HuMa, Pluralisme Hukum: Sebuah Pendekatan Interdisiplin, (Jakarta: Ford Foundation - HuMa, 2005), hlm. 7.

${ }_{27}$ Satjipto Rahardjo, Budaya Hukum dalam Permasalahan Hukum di Indonesia, Ceramah Seminar Hukum Nasional ke IV, Badan Pembinaan Hukum Nasional, Jakarta, 1979, hlm. 28.

${ }^{28}$ I Nyoman Nurjaya. Pengelolaan Sumber Daya Alam dalam Perspektif Antropologi Hukum. (Malang: Universitas Negeri Malang, 2006), hlm. 33.

${ }^{29}$ Bahan-bahan diambil dari BHM Vlekke, 2008, Nusantara: Sejarah Indonesia, Jakarta: KPG/Gramedia; MC Ricklefs, 2001, Sejarah Indonesia Modern 1200-2004, Jakarta: Serambi; Marwati Djoened Poesponegoro dan Nugroho Notosusanto, 1993; Snouck Hurgronje, 1985 (1906), Aceh di Mata Kolonialis, Jakarta: Yayasan Soko Guru; Snouck Hurgronje, 1995 (1923), Kumpulan Karangan Snouck Hurgronje, Jakarta: INIS; "Aceh", wikipedia, lihat: Agung Djojosoekarto, et.al. (Eds.). Kebijakan Otonomi Khusus Papua. (Jakarta: Kemitraan, 2008), hlm. 12.
} 
Sebelumnya, Undang-undang Nomor 44 Tahun 1999, Pasal 3 ayat (1) Keistimewaan merupakan pengakuan dari bangsa Indonesia yang diberikan kepada Daerah karena perjuangan dan nilai-nilai hakiki masyarakat yang tetap dipelihara secara turun temurun sebagai landasan spiritual, moral, dan kemanusiaan. (2) Penyelenggaraan Keistimewaan meliputi: a. penyelenggaraan kehidupan beragama; b. penyelenggaraan kehidupan adat; $c$. penyelenggaraan pendidikan; dan d. peran ulama dalam penetapan kebijakan Daerah. Pasal 4 ayat (1) Penyelenggaraan kehidupan beragama di Daerah diwujudkan dalam bentuk pelaksanaan syariat Islam bagi pemeluknya dalam bermasyarakat. (2) Daerah mengembangkan dan mengatur penyelenggaraan kehidupan beragama, sebagaimana dimaksud pada ayat (1), dengan tetap menjaga kerukunan hidup antar umat beragama.

Pada masa reformasi, Pemerintahan di bawah Presiden B.J. Habibie, Keputusan Perdana Menteri Republik Indonesia Nomor 1/Missi/1959 tentang Keistimewaan Provinsi Aceh diperkuat dengan dibuatnya UU No. 44 Tahun 1999 tentang Penyelenggaraan Keistimewaan Provinsi Daerah Istimewa Aceh. Bahkan, Habibie menambah keistimewaan Aceh dengan memasukkan klausul "peran ulama dalam penetapan kebijakan daerah." Klausul ini ditindaklanjuti dengan membentuk sebuah badan yang anggotanya terdiri atas para ulama.

Selanjutnya, UU No. 11 Tahun 2006 tentang Pemerintahan Aceh menyebutkan, bahwa Aceh adalah daerah provinsi yang merupakan kesatuan masyarakat hukum yang bersifat istimewa dan diberi kewenangan khusus untuk mengatur dan mengurus sendiri urusan pemerintahan dan kepentingan masyarakat setempat sesuai dengan peraturan perundangundangan dalam sistem dan prinsip Negara Kesatuan Republik Indonesia berdasarkan Undang-undang Dasar Negara Republik Indonesia Tahun 1945, yang dipimpin oleh seorang Gubernur.

Dalam Pasal 142 (1) ditentukan, Pemerintah mempunyai kewenangan menetapkan norma, standar, dan prosedur penataan ruang dalam penyusunan Rencana Tata Ruang Wilayah Aceh, dan kabupaten/kota dengan memperhatikan pembangunan berkelanjutan dan kelestarian fungsi lingkungan hidup. (2) Perencanaan, penetapan, dan pemanfaatan tata ruang Aceh didasarkan pada keistimewaan dan kekhususan Aceh dan saling terkait dengan tata ruang nasional dan tata ruang kabupaten/kota. "Keistimewaan dan kekhususan Aceh" yang dimaksud secara implisit dapat dihubungkan dan keberadaan pemerintahan Mukim yang berperan dalam perencanaan pembangunan (termasuk tata ruang) dan pengelolaan sumberdaya alam di wilayah kewenangannya.

\section{Pembangunan Berkelanjutan}

Pembangunan berkelanjutan itu sendiri adalah Perubahan positif sosial ekonomi yang tidak mengabaikan sistem ekologi dan sosial di mana masyarakat bergantung kepadanya. Keberhasilan penerapannya memerlukan kebijakan, perencanaan dan proses pembelajaran sosial yang terpadu, viabilitas politiknya tergantung pada dukungan penuh masyarakat melalui pemerintahannya, kelembagaan sosialnya, dan kegiatan dunia usahanya (Otto Soemarwoto 2006).

Secara implisit, definisi tersebut menurut Hegley, Jr. 1992 mengandung pengertian strategi imperatif bagi pembangunan berkelanjutan sebagai berikut:

a. Berorientasi untuk pertumbuhan yang mendukung secara nyata tujuan ekologi, sosial, dan ekonomi.

b. Memperhatikan batas-batas ekologis dalam konsumsi materi dan memperkuat pembangunan kualitatif pada tingkat masyarakat dan individu dengan distribusi yang adil.

c. Perlunya campur tangan pemerintah, dukungan, dan kerja sama dunia usaha dalam upaya konservasi dan pemanfaatan yang berbasis sumber daya. 
d. Perlunya keterpaduan kebijakan dan koordinasi pada semua tingkat dan antara yurisdiksi politik terkait dalam pengembangan energi bagi pertumbuhan kebutuhan hidup.

e. Bergantung pada pendidikan, perencanaan, dan proses politik yang terinformasikan, terbuka, dan adil dalam pengembangan teknologi dan manajemen.

f. Mengintegrasikan biaya sosial dan biaya lingkungan dari dampak pembangunan ke dalam perhitungan ekonomi.

Dengan demikian, maka konsep pembangunan berkelanjutan berkembang lebih jauh, tidak lagi terpaku pada konsep awal yang lebih terpokus pada pemeliharaan kelestarian keseimbangan lingkungan semata-mata.

Konsep yang bersifat holistik tersebut dijabarkan secara lebih rinci oleh Serageldin dan Steer (1994) yang mengkategorisasikan adanya empat jenis capital stock yaitu:

a. natural capital stock: berupa segala sesuatu yang disediakan oleh alam;

b. human-made capital stock: antara lain dalam wujud investasi dan teknologi;

c. human capital stock: berupa sumberdaya manusia dengan segenap kemampuan, ketrampilan dan perilakunya;

d. social capital stock: berupa organisasi sosial, kelembagaan atau institusi ${ }^{30}$

\section{Penataan Ruang dan Tata Ruang Aceh}

Menurut istilah geografi umum, yang dimaksud ruang adalah seluruh permukaan bumi yang merupakan lapisan biosfer, tempat hidup tumbuh-tumbuhan, hewan dan manusia. Sedangkan menurut Undang-Undang No. 26 Tahun 2007 tentang Penataan Ruang menyebutkan bahwa ruang adalah wadah yang meliputi ruang darat, ruang taut, dan ruang udara, termasuk ruang di dalam bumi sebagai satu kesatuan wilayah, tempat manusia dan makhluk lain hidup, melakukan kegiatan, dan memelihara kelangsungan hidupnya.

Untuk mewujudkan pembangunan yang berkelanjutan, maka diperlukan upaya penataan ruang. Penataan ruang menyangkut seluruh aspek kehidupan sehingga masyarakat perlu mendapat akses dalam proses perencanaan tersebut. Penataan ruang adalah suatu sistem proses perencanaan tata ruang, penanfaatan ruang, dan pengendalian pemanfaatan ruang. Kegiatan penataan ruang dimaksudkan untuk mengatur ruang dan membuat suatu tempat menjadi bernilai dan mempunyai ciri khas dengan memperhatikan kondisi fisik wilayah Negara Kesatuan Republik Indonesia yang rentan terhadap bencana, potensi sumber daya alam, sumber daya manusia, dan sumber daya buatan; kondisi ekonomi, sosial, budaya, politik, hukum, pertahanan keamanan, lingkungan hidup, serta ilmu pengetahuan dan teknologi sebagai satu kesatuan, geostrategi, geopolitik, dan geoekonomi (UU No. 26 Tahun 2007) ${ }^{31}$

Pelaksanaan penataan ruang adalah pencapaian tujuan penataan ruang melalui pelaksanaan perencanaan tata ruang, pemanfaatan ruang, dan pengendalian pemanfaatan ruang. Untuk perencanaan tata ruang yang mencakup rencana struktur ruang dan pola ruang harus memperhatikan aspek budaya yang ada, seperti dengan adanya kawasan strategis dan kawasan pusaka/budaya. Setiap perencanaan tata ruang perlu melakukan survey mengenai kearifan lokal atau budaya yang terkait di dalamnya yang akan menentukan bentuk dari regulasi penataan ruang. Hal ini juga dilakukan agar masyarakat sebagai bagian dari budaya ikut terlibat dalam perencanaan tata ruang. Dalam suatu wilayah pada umumnya memiliki lembaga pengelolaan tersendiri yang melibatkan tokoh-tokoh masyarakat yang mengetahui banyak mengenai kearifan lokal yang ada. Di sinilah peran tokoh-tokoh adat tersebut

30 Eko Budihardjo, et.al. Kota Berkelanjutan (Sustainable City). (Bandung: Alumni, 2009), hlm. 19.

${ }^{31}$ Robert J. Kodoatie, et.al.,Op.Cit., hlm. 399. 
dianggap penting dalam mengharmonisasikan kearifan lokal dengan regulasi penataan ruang ${ }^{32}$.

\section{Kearifan Lokal Masyarakat Adat Mukim}

Dalam berbagai kajian dan penelitian soal Aceh selama ini, terkait dengan pengelolaan sumberdaya alam, lingkungan dan tata ruang mencurahkan perhatian serius terhadap kearifan lokal. Berdasarkan sejumlah literatur, dapat ditarik makna kearifan lokal adalah nilai-nilai, norma, hukum-hukum dan pengetahuan yang dibentuk oleh ajaran agama, kepercayaan-kepercayaan, tata nilai tradisional dan pengalaman-pengalaman yang diwariskan oleh leluhur yang akhirnya membentuk sistem pengetahuan lokal yang digunakan untuk memecahkan permasalahan-permasalahan sehari-hari oleh masyarakat.

Cerminan dari kearifan lingkungan masyarakat yang bercorak religio-magis secara konkrit terkristalisasi dalam produk hukum masyarakat lokal, yang dalam ancangan antropologi hukum disebut hukum kebiasaan (customary law), hukum rakyat (folk law), hukum penduduk asli (indigenous law), hukum tidak tertulis (unwritten law), atau hukum tidak resmi (unofficial law), atau dalam konteks Indonesia disebut hukum adat (adat law/adatrecht). ${ }^{33}$

Istilah Mukim berasal dari bahasa arab yaitu muqim yang berarti penduduk suatu tempat atau tempat tinggal. Mukim berarti "berkedudukan pada suatu tempat." Oleh orang Aceh, diterjemahkan sebagai suatu wilayah tempat menetap yang terdiri dari beberapa perkampungan. ${ }^{34}$ Pengertian yang sama juga dinyatakan oleh Anthony Reid bahwa mukim pada awalnya adalah himpunan beberapa desa untuk mendukung sebuah masjid yang dipimpin oleh seorang imam (bahasa Aceh Imuem). ${ }^{35}$

Sedangkan A.Hasjmy berpendapat, mukim merupakan federasi dari gamponggampong, yang mana satu mukim paling kurang terdiri dari delapan gampong. Federasi mukim dipimpin oleh seorang Imeum dan seorang Kadli. Pada tiap-tiap mukim didirikan paling kurang sebuah masjid. ${ }^{36}$ Dalam perkembangan sejarahnya, hingga kini mukim sebagai kesatuan masyarakat hukum memiliki hak dan kekuasaan dalam mengatur dan mengurus kepentingan masyarakat setempat, terutama dalam meningkatkan kesejahteraan masyarakat memiliki peran dan posisi yang strategis karena: (1) Mempunyai susunan pemerintahan asli berdasarkan hak asal usul yang bersifat istimewa; (2) Penyelenggaraan pemerintahan mukim merupakan sub sistem dari penyelenggaraan pemerintahan Provinsi Nanggroe Aceh Darussalam dan juga sub sistem Pemerintahan Nasional; (3) Mukim dapat melakukan perbuatan hukum, baik hukum publik, hukum perdata maupun hukum adat, memiliki harta kekayaan, harta benda, dan bangunan serta dapat dituntut dan menuntut di pengadilan; (4) Sebagai perwujudan demokrasi, di mukim dibentuk Majelis Permusyawaratan Mukim atau sebutan lain sebagai lembaga yang menampung dan menyalurkan aspirasi masyarakat serta mengawasi jalannya pemerintahan mukim; (5) Di gampong dapat dibentuk lembaga adat sesuai dengan kebutuhan yang merupakan mitra kerja Pemerintahan Mukim; (6) Mukim memiliki sumber pembiayaan; (7) Mukim

\footnotetext{
${ }^{32}$ Mulia Darmawan, Kearifan Lokal dalam Pembangunan Penataan Ruang. Di www. Mulia DarmawanBlog. Com. Diakses tanggal 9 Maret 2014.

${ }^{33}$ I Nyoman Nurjaya. Op.Cit., hlm. 8.

${ }^{34}$ Snouck Hurgronye. "The Achehnese". Diterjemahkan oleh Singarimbun, et.al., Aceh Dimata Kolonialis. (Jakarta: Yayasan Soko Guru, 1985), hlm. 90.

${ }^{35}$ Anthony Reid. "The Contest for North Sumatera, the Netherlands and Britain 1858-1898." Oxford University Press. 1969. Diterjemahkan oleh Masri Maris, Asal Mula Konflik Aceh, Dari Perebutan Pantai Timur Sumatera Hingga Akhir Kerajaan Aceh ke-19. (Jakarta: Yayasan Obor Indonesia, edisi kedua 2007), hlm. 3.

${ }^{36}$ A. Hasjmy. 59 Tahun Aceh Merdeka di Bawah Pemerintahan Ratu. (Jakarta: Bulan Bintang, 1977), hlm. 134.
} 
mempunyai wewenang untuk mendamaikan perkara/sengketa dari pada warganya dan adat serta sengketa adat lainnya; (8) Mukim sebagai koordinator penyelenggaraan pemerintahan gampong dan koordinator pelaksanaan syari'at Islam."37

\section{Kesimpulan}

Aceh, sebagai suatu wilayah, selain mengikuti praktik dan ketentuan hukum nasional, juga memiliki lembaga adat dan nilai-nilai tradisi/budaya dengan pengelolaan tersendiri yang melibatkan tokoh-tokoh masyarakat yang mengetahui banyak mengenai kearifan lokal yang ada di kawasan itu. Di sinilah peran tokoh-tokoh adat, tokoh agama dan tokoh sosial-budaya dianggap penting dalam mengharmonisasikan kearifan lokal dengan regulasi penataan ruang dan pembangunan berwawasan lingkungan yang berkelanjutan

\section{Daftar Pustaka}

I Nyoman Nurjaya. "Menuju Pengakuan Kearifan Lokal Dalam Pengelolaan Sumber Daya Alam: Perspektif Antropologi Hukum." Dalam Rachmad Safa'at, et.al. Negara, Masyarakat Adat dan Kearifan Lokal. (Malang: In-Trans Publishing, 2008), hlm. 8.

Rachmad Safa'at. Rekonstruksi Politik Hukum Pangan dari Ketahanan Pangan ke Kedaulatan Pangan. (Malang: UB Press, 2013), hlm. 3.

Rachmad Safa'at. 'Kearifan lingkungan Masyarakat Adat dalam Pengelolaan Sumber Daya Alam Berkelanjutan: Analisis Kasus Masyarakat Adat Baduy dalam Konteks Pelaksanaan Otonomi Daerah.” Dalam Rachmad Safa'at, et.al. Negara, Masyarakat Adat dan Kearifan Lokal. (Malang: In-Trans Publishing, 2008), hlm. 61.

Sri Wahyuni, et.al. "Kearifan Lingkungan pada Masyarakat Aceh." Dalam Bunga Rampai Kearifan Lingkungan. (Jakarta: Kementerian Lingkungan Hidup, 2002), hlm. 586.

Jonny Purba. "Penataan Ruang Tradisional Sebagai Wujud Kearifan Lingkungan pada Masyarakat Batak Toba." Dalam Bunga Rampai Kearifan Lingkungan. (Jakarta: Kementerian Lingkungan Hidup, 2002), hlm. 654.

Darmawan M. Ali. "Pemerintahan Daerah Berbasis Kearifan Lokal." Disertasi. (Malang: Program Doktor Ilmu Administrasi Universitas Brawijaya, 2013), hlm. 140.

Mauro Zamboni. The Policy of Law: A Legal theoritical framework. (Oxford and Portland Oregon: Hart Publishing, 2007).

Imam Syaukani dan A. Ahsin Thohari. Dasar-dasar Politik Hukum, cet. Ke-8, (Jakarta: Rajawali Press, 2012), hlm. 40.

C.F.G. Sunaryati Hartono. Politik Hukum Menuju Satu Sistem Hukum Nasional. (Bandung: Alumni, 1991), hlm. 1-2.

Bagir Manan. Menyongsong Fajar Otonomi Daerah. (Yogyakarta: FH UII, 2001), hlm. 180.

Abdul Hakim G. Nusantara. Politik Hukum Indonesia. (Jakarta: YLBHI, 1988), hlm. 20.

Adi Sulistiyono. Negara Hukum: Kekuasaan, Konsep, dan paradigma Moral. (Surakarta: LPP dan UNS Press, 2008), hlm. 52. Sebagaimana dikutip oleh Muhammad Akib. Politik Hukum Lingkungan. (Jakarta: PT. RajaGrafindo Persada, 2013), hlm. 6.

Imam Koeswahyono. Hukum Penatagunaan Tanah dan Penataan Ruang di Indonesia, (Problematika antara Teks dan Konteks). (Malang: UB Press, 2012), hlm. 104.

37 Anonimous. Petunjuk Teknis Penyelenggaraan Pemerintahan Mukim dalam Provinsi Nanggroe Aceh Darussalam. (Banda Aceh, Biro Pemerintahan Sekretariat Daerah Provinsi Nanggroe Aceh Darussalam, 2004), hlm. 4-5. 
Mustafa Lutfi \& Luthfi J. Kurniawan. Perihal Negara, Hukum dan Kebijakan Publik. Perspektif Politik Kesejahteraan, Kearifan Lokal, yang pro Civil Society dan Gender. (Malang: Setara Press, 2012), hlm. 13.

M. Solly Lubis. Kebijakan Publik. (Bandung: Mandar Maju, 2007), hlm. 5.

Thomas A. Birkland. An Introduction to the Policy Process, Theories, Concepts, and Models of Public Policy Making. Third Edition. (New York: M.E. Sharpe, Inc., 2011), hlm. 8.

Djoko Sujarto. Pilihan Strategis Suatu teknik Pengambilan Keputusan dalam Perencanaan Wilayah dan Kota. (Bandung: Penerbit ITB, 2001), hlm. 2.

Ibid, hlm. 4.

Robert J. Kodoatie, et.al. Tata Ruang Air. Pengelolaan Bencana, Pengelolaan Infrastruktur, Penataan Ruang Wilayah, Pengelolaan Lingkungan Hidup. (Yogyakarta: Penerbit Andi, 2010), hlm. 406.

Edi Suharto. Modal Sosial dan Kebijakan Publik. Http://www.policy.hu/suharto, diunduh tanggal 6 Juli 2014., hlm. 2.

John Griffiths, "What is Legal Pluralism", Journal of Legal Pluralism and Unoficial Law. Number 24/1986, hlm. 1.

Rikardo Simarmata, "Mencari Karakter Aksional dalam Pluralisme Hukum" dalam Tim HuMa, Pluralisme Hukum: Sebuah Pendekatan Interdisiplin, (Jakarta: Ford Foundation - HuMa, 2005), hlm. 7.

Satjipto Rahardjo, Budaya Hukum dalam Permasalahan Hukum di Indonesia, Ceramah Seminar Hukum Nasional ke IV, Badan Pembinaan Hukum Nasional, Jakarta, 1979, hlm. 28.

I Nyoman Nurjaya. Pengelolaan Sumber Daya Alam dalam Perspektif Antropologi Hukum. (Malang: Universitas Negeri Malang, 2006), hlm. 33.

Bahan-bahan diambil dari BHM Vlekke, 2008, Nusantara: Sejarah Indonesia, Jakarta: KPG/Gramedia; MC Ricklefs, 2001, Sejarah Indonesia Modern 1200-2004, Jakarta: Serambi; Marwati Djoened Poesponegoro dan Nugroho Notosusanto, 1993; Snouck Hurgronje, 1985 (1906), Aceh di Mata Kolonialis, Jakarta: Yayasan Soko Guru; Snouck Hurgronje, 1995 (1923), Kumpulan Karangan Snouck Hurgronje, Jakarta: INIS; "Aceh", wikipedia, lihat: Agung Djojosoekarto, et.al. (Eds.). Kebijakan Otonomi Khusus Papua. (Jakarta: Kemitraan, 2008), hlm. 12.

Eko Budihardjo, et.al. Kota Berkelanjutan (Sustainable City). (Bandung: Alumni, 2009), hlm. 19.

Mulia Darmawan, Kearifan Lokal dalam Pembangunan Penataan Ruang. Di www. Mulia DarmawanBlog. Com. Diakses tanggal 9 Maret 2014.

Snouck Hurgronye. "The Achehnese". Diterjemahkan oleh Singarimbun, et.al., Aceh Dimata Kolonialis. (Jakarta: Yayasan Soko Guru, 1985), hlm. 90.

Anthony Reid. "The Contest for North Sumatera, the Netherlands and Britain 1858-1898." Oxford University Press. 1969. Diterjemahkan oleh Masri Maris, Asal Mula Konflik Aceh, Dari Perebutan Pantai Timur Sumatera Hingga Akhir Kerajaan Aceh ke-19. (Jakarta: Yayasan Obor Indonesia, edisi kedua 2007), hlm. 3.

A. Hasjmy. 59 Tahun Aceh Merdeka di Bawah Pemerintahan Ratu. (Jakarta: Bulan Bintang, 1977), hlm. 134.

Anonimous. Petunjuk Teknis Penyelenggaraan Pemerintahan Mukim dalam Provinsi Nanggroe Aceh Darussalam. (Banda Aceh, Biro Pemerintahan Sekretariat Daerah Provinsi Nanggroe Aceh Darussalam, 2004), hlm. 4-5. 